\title{
Expression of DnaK and HtrA genes under high temperatures and their impact on thermotolerance of a Salmonella serotype isolated from tahini product
}

\author{
Reda M. Gaafar ${ }^{1 *}$ (D) Marwa M. Hamouda ${ }^{1}$, Khalid A. El-Dougdoug ${ }^{2}$ and Sameh Fayez Fouad ${ }^{1}$
}

\begin{abstract}
Background: Salmonella is considered to be the second largest source of infection in food-borne diseases. It is also considered one of the most important dangers particularly in the meat and dairy industry. Therefore, the main objective of our study was to determine the relationship between thermotolerance of a Salmonella serotype and the expression of DnaK and HtrA genes.

Results: In this study, expression of the two genes DnaK and HtrA was compared under four different temperatures $37^{\circ} \mathrm{C}, 42^{\circ} \mathrm{C}, 50^{\circ} \mathrm{C}$, and $55^{\circ} \mathrm{C}$ in two serotypes of Salmonella enterica subsp. enterica. One of them was isolated from tahini product and identified as Salmonella enterica subsp. enterica serovar choleraesuis. This identified serotype was found to be more thermotolerant than the second serotype (Salmonella enterica subsp. enterica serovar typhimurium (ATCC 13311)), which was used as reference. This conclusion was based on $D$ and $Z$ values, which were used to compare thermoresistance ability of the two serotypes under four different temperatures $60^{\circ} \mathrm{C}, 65^{\circ} \mathrm{C}$, $70^{\circ} \mathrm{C}$, and $75^{\circ} \mathrm{C}$. In addition, the results of qRT-PCR showed that after $43^{\circ} \mathrm{C}$ (induction temperature), the relative expression (fold change) of DnaK and HtrA genes increased up to 5 and 47, respectively, comparing to their expression at $37^{\circ} \mathrm{C}$.
\end{abstract}

Conclusions: Thermotolerance of the identified S. choleraesuis serotype showed significantly high expression levels of DnaK and HtrA genes.

Keywords: Salmonella, Thermotolerance, qRT-PCR, D value, $Z$ value, Relative gene expression

\section{Background}

Salmonellosis is one of the most well-known food-borne diseases that causes annually over one million infections [1]. Thermal treatment of food is considered as the most effective and cheapest method used to eliminate pathogenic microbes such as Salmonella, yet the microbial resistance against heat is a very important factor that limits the thermal treatment of food [2]. Salmonella is relatively heat resistant as a member of Enterobacteriaceae comparing to $E$. coli, where the $D$ values of Salmonella spp. and E. coli in fried poultry meat at $70^{\circ} \mathrm{C}$ are 13.2 and $2.5 \mathrm{~s}$, respectively [3]. In addition, the $D$ value of Salmonella spp.

\footnotetext{
* Correspondence: redagaafar@science.tanta.edu.eg; redagaafar@gmail.com 'Botany Department, Faculty of Science, Tanta University, Tanta 31527, Egypt Full list of author information is available at the end of the article
}

at $70^{\circ} \mathrm{C}$ was found to be $24 \mathrm{~s}$ at water activity of 0.72 in poultry meat [4] and this is a high thermotolerance degree for a member of Enterobacteriaceae.

It is well known that the causes of thermal resistance in bacteria vary greatly from surrounding environmental to genetic causes $[5,6]$. In addition, heat shock proteins (HSPs) are noted to play a pivotal role in the survival of bacteria from damage caused by exposure to heat. Moreover, these HSPs are essential to maintain the life of bacteria during exposure to various kinds of stress [7]. A study conducted by Sirsat et al. [8] indicated a correlation between relatively high expression rates of some heat shock genes and thermal tolerance in Salmonella. Furthermore, it is well known that Salmonella gains more thermoresistance if it is subjected to sublethal temperature 
and even becomes more severe in virulence [8]. However, less is known about the variability in heat tolerance on the serotype level. It seems that some serotypes are more heat resistant than others, where this variation was due to difference in $D$ and $Z$ values as observed in S. senftenberg and S. typhimurium serotypes [9].

One of the heat shock genes is HtrA gene. It codes for a degradation protein (DegP), which acts as a molecular chaperone and as a periplasmic endopeptidase enzyme that maintains the periplasm. The mutants of this gene were found to be not able to grow at temperature above $42^{\circ} \mathrm{C}$ [10], where HtrA mutant Salmonella suffers highly attenuated survival during the infection [11]. Another heat shock gene is DnaK gene. It codes for HSP70 protein, which is considered as the most important heat shock protein. It is a molecular chaperone, which makes the refolding of the misfolded proteins and disperses the aggregated protein molecules in stress conditions [12]. It was reported that the accumulation of heat shock proteins is directly proportional to the elevation of the temperature. However, major heat shock proteins, including HSP70, were not thought to have direct relationship to the thermotolerance because one protein of molecular weight $34 \mathrm{kDa}$ disappeared rapidly following a temperature downshift $\left(48^{\circ} \mathrm{C}\right.$ to $\left.37^{\circ} \mathrm{C}\right)$ proving that this protein is related to thermotolerance and HSPs are not [13]. However, several recent studies found that HSP100 (ClpB) has a crucial role in thermotolerance mechanism $[14,15]$ by performing a complex with HSP70 heat shock protein $[16,17]$.

The main objective of this study was to compare the expression of two heat shock genes DnaK and HtrA under four different temperatures $37^{\circ} \mathrm{C}, 42{ }^{\circ} \mathrm{C}, 50{ }^{\circ} \mathrm{C}$, and $55^{\circ} \mathrm{C}$ in two serotypes S. choleraesuis and S. typhimurium. Moreover, thermotolerance of the two Salmonella serotypes was evaluated and compared.

\section{Methods}

\section{Isolation of Salmonella}

Thirty-two samples of tahini product from a production line, which was known to be suffering from contamination with Salmonella, were examined for presence of Salmonella spp. Examination of samples was done following the ISO standard 6579:2002 [18] (horizontal method for the detection of Salmonella spp.). The three main steps of isolation of Salmonella, pre-enrichment in buffered peptone medium, selective enrichment in Muller-Kauffmann tetrathionate (MKTT), and Rappaport-Vassiliadis (RV) enrichment broths and streaking on xylose lysine desoxycholate agar (XLD) and Hektone enteric agar, were done followed by biochemical and serological confirmations. All the media used for Salmonella isolation were purchased from Oxoid-Thermo Fisher Scientific (UK).

\section{Molecular identification using 16s RNA}

16s RNA gene analysis was performed in Clinilab Laboratories, Al-Maadi, Cairo, Egypt. Bacterial DNA was extracted using a bacterial DNA extraction kit (Qiagen, USA) according to Green and Sambrook [19]. The extracted DNA was treated with RNase A solution (10 ng/ $\mu \mathrm{l})$ to remove any contamination with RNA. Then, PCR was performed using the universal (16s RNA forward and reverse) primers (Table 1), which were designed to amplify $1500 \mathrm{bp}$ fragment of the 16s rRNA gene region. The PCR was carried out for 30 cycles at $94^{\circ} \mathrm{C}$ for $1 \mathrm{~min}, 55^{\circ} \mathrm{C}$ for $1 \mathrm{~min}$, and $72^{\circ} \mathrm{C}$ for $2 \mathrm{~min}$ to each cycle. The PCR amplicon was sequenced using the same amplification primers. Automated DNA sequencing based on enzymatic chain terminator technique [20] was performed using 3130X DNA Sequencer (Genetic Analyzer, Applied Biosystems, Hitachi, Japan). The consensus sequence of forward and reverse reads was then compared with sequences in NCBI GenBank using similarity analysis BLASTN tool. The multiple sequence alignment (MSA) and molecular phylogenetic analyses were performed using BioEdit software [21].

\section{Serotype determination}

The serotype of the isolated Salmonella was determined according to Kauffman-White -Le Minor scheme that was updated in Grimont and Weill [22]. A group of antisera containing omnivalent, polyvalent, and monovalent antisera (Sifin, Berlin, Germany) was used to determine the serotype of the isolated bacteria in three separated tests (three different single colonies). A single colony in each test was first mixed with $1 \mathrm{ml}$ of sterilized $1 \% \mathrm{NaCl}$ saline solution. Then, one drop of antisera was added and the agglutinations were observed and recorded.

\section{Assessment of bacterial thermotolerance}

In order to determine the thermotolerance of the isolated bacteria, $D$ and $Z$ values were measured in aqueous solution taking Salmonella typhimurium ATCC 13311, taxid: 90371 as a reference [23]. Both bacteria were grown in a nutrient medium: brain heart infusion broth (Oxoid) at $37^{\circ} \mathrm{C}$ for 24 $h$. Then, the bacterial broth was distributed to new fresh brain heart infusion broth media and grown under different temperatures $\left(60^{\circ} \mathrm{C}, 65^{\circ} \mathrm{C}, 70^{\circ} \mathrm{C}\right.$, and $\left.75^{\circ} \mathrm{C}\right)$. The count of survival bacteria was done at three time points $(1,2$, and 3 $\mathrm{min}$ ) for each temperature using a differentiative selective medium (brilliant green bile agar) to determine $D$ values of bacteria at these temperatures. Using $D$ values, a graph was constructed for $Z$ value determination in which $X$-axis represented the logarithm of survival bacterial counts and $Y$ axis showed the temperatures. The $Z$ value was obtained by inverting the curve slope. The results of both serotypes were compared using Tukey's multiple comparisons test of GraphPad Prism6 software, where alpha $=0.05$ was selected. 
Table 1 Sequences of primers used in this study for 16s bacterial identification and for heat shock gene (DnaK and HtrA) expression analysis

\begin{tabular}{|c|c|}
\hline Primer name & Sequence $\left(5^{\prime}-3^{\prime}\right)$ \\
\hline 16s RNA forward & 5'-AACTGGAAGGTGGGGAT-3' \\
\hline 16s RNA reverse & 5'-AGGAGGTCCAACCGCA-3' \\
\hline 16s RNA-qRT-PCR-F & 5'-TCCTACGGGAGGCAGCAGT-3' \\
\hline 16s RNA-qRT-PCR-R & 5'-GGACTACCAGGGTATCTAATCCTGTT-3' \\
\hline DnaK-StF (S. typhimurium) & 5'-CGCTTCCAGGACGAAGAAGT-3' \\
\hline DnaK-StR (S. typhimurium) & 5'-CGAGG TCGTAAACCGCGATA-3' \\
\hline DnaK-ScF (S. choleraesuis) & 5'-CGCTTCCAGGACGAAGAAGT-3' \\
\hline DnaK-ScR (S. choleraesuis) & 5'-CGAGG TCGTAAACCGCGATA-3' \\
\hline HtrA-StF (S. typhimurium) & 5'-CGACGAACAACTCTGGCTCA-3' \\
\hline HtrA-StR (S. typhimurium) & 5'-TTCAAG GGTGTCGAGATGGC-3' \\
\hline HtrA-ScF (S. choleraesuis) & 5'-GAGTGCACTGGCTCTGAGTT-3' \\
\hline HtrA-ScR (S. choleraesuis) & 5'-TTCACC GTGGTGCTACCTTC-3' \\
\hline
\end{tabular}

\section{DnaK and HtrA expression analysis} RNA extraction

To extract the total RNA, bacterial cells were first exposed to $37^{\circ} \mathrm{C}, 42^{\circ} \mathrm{C}, 47^{\circ} \mathrm{C}, 50^{\circ} \mathrm{C}$, and $55^{\circ} \mathrm{C}$ for $18 \mathrm{~h}$, and then, total RNA was extracted using RNeasy Mini Kit, cat. no.: 74104 (Qiagen, Valencia, CA, USA). Afterwards, RNA extract was treated with RNase-free DNase (Qiagen-DNA wipe out) to remove residual genomic DNA. Subsequently, the verification of RNA extraction was performed using $1.5 \%$ agarose gel electrophoresis. The purified RNA was reverse transcribed into cDNA using reverse transcription Qiagen kit (QuantiTect ${ }^{\oplus}$ Reverse Transcription, cat. no.: 205311). Finally, the obtained cDNA was verified using $1.5 \%$ agarose gel electrophoresis.

\section{Quantitative real-time $P C R$}

To measure the relative expression of the target genes (DnaK and HtrA), quantitative real-time PCR (qRT-PCR) assay was performed on cDNA using the gene-specific primers (Table 1) and a ready-to-use qRT-PCR kit (QuantiTect SYBR Green PCR). The transcripts of these two genes were analyzed on Rotor-Gene Q48 Thermocycler. The 16s RNA gene (housekeeping gene) expression was used as a reference gene and analyzed in parallel using specific primers (16s RNA-qRT-PCR-F and R) of 16s RNA gene of Gram-negative bacteria (Table 1). Calculation of the relative gene expression was done according to $2^{-\Delta \Delta C t}$ method for normalizing the cycle threshold values $[8,24]$. The gene expression of DnaK and HtrA in both serotypes was compared using Tukey's multiple comparisons test of GraphPad Prism6 software, where alpha $=0.05$ was selected.

\section{Results and discussion}

\section{Bacterial isolate identification}

Four samples (Salmonella-positive samples) of the total 32 examined tahini samples were found to be infected with Salmonella. These isolated bacteria gave the specific characteristics of Salmonella: dark colonies with black center on XLD, black colonies on Hektoen enteric agar, negative urease reaction on urea agar, sulfite reduction on triple sugar iron agar (TSI) and lysine iron agar (LI) with gas formation in TSI, negative $\beta$-galactosidase, negative indole, and negative Voges-Proskauer test. The confirmatory tests using poly O-Vi (somatic and capsular) antisera and poly $\mathrm{H}$ (flagellar) antisera were performed, and the results showed that the isolated bacteria are Salmonella.

For molecular identification of the Salmonella isolates, the 16s RNA gene analysis was performed. The PCR fragment of $475 \mathrm{bp}$ was amplified and sequenced. Then, sequence BLASTN analysis was performed on the GenBank (NCBI) databases. A 99\% sequence similarity was found to be with Salmonella enterica subsp. enterica, which indicates that the isolated bacteria are Salmonella enterica subsp. enterica serotype choleraesuis. The sequence of $16 \mathrm{~s}$ gene of the isolated bacteria was deposited in NCBI GenBank and was given the following accession no. MK041288.1.

Moreover, serological analysis was performed to determine the specific serotype as the 16s RNA analysis is not a precise method at the levels lower than species in bacteria. Therefore, full Salmonella serological identification was performed on three isolates from the four positive samples. The results of the full serological tests showed that the antigenic formula of the three bacterial isolates is somatic antigen 6, 7; flagellar antigen phase 1: c; and flagellar antigen phase 2: 1, 5. By referring to the Kaufmann-White-Le Minor scheme [22], the bacterial serotype was confirmed as Salmonella enterica subsp. enterica serovar choleraesuis.

For identification of Salmonella serotypes, till now, serotyping using antisera and pulsed-field gel electrophoresis (PFGE) is the only accredited traditional methods. 
However, serotyping using antisera has an advantage of being cheaper than any other DNA dependent methods. Even the PFGE method is still expensive and takes much time for comparing bacterial serotypes [25]. In addition, PFGE does not show a unified profile for different strains of the same serotype [26]. On the other hand, the rates of concordance at the species level by using partial sequencing 16s rRNA gene and sequence alignment technique were found to be $80 \%$ [27]. Therefore, it seems that using $16 \mathrm{~s}$ rRNA analysis is not trusted at taxonomic levels lower than species. So, in this study, we considered the partial sequencing of 16s rRNA gene as a primary identification method and the results were confirmed using the serotyping procedure. Some new serotype identification techniques are depending on 16s rRNA like 16s rRNA PCRhigh-resolution melt analysis assay (HRMA), which is quite accurate [28] however it still needs more data to cover all serotypes of Salmonella [29]. Therefore, about 2600 serotypes are reported because of limited resolution and lower sensitivity of 16s rRNA gene analysis compared to metagenomic sequencing method [30,31].

\section{Thermotolerance analysis}

In order to evaluate the thermotolerance of the isolated bacterium (serotype), S. choleraesuis in parallel with Salmonella typhimurium ATCC 13311 (reference bacterium), $D$ value and $Z$ value determination of both serotypes in aqueous nutrient solutions at water activity of 0.98 was performed under different temperatures $60^{\circ} \mathrm{C}, 65^{\circ} \mathrm{C}, 70^{\circ} \mathrm{C}$, and $75^{\circ} \mathrm{C}$. The results showed that the $D$ values of $S$. choleraesuis at the previously mentioned temperatures are 45.6, 33.6, 21.6, and $9.6 \mathrm{~s}$, respectively, while the corresponding $D$ values for $S$. typhimurium were 43.2, 35.4, 16.2, and $3.6 \mathrm{~s}$, respectively. The $Z$ values were found to be 4.9 and 4.5 , respectively. Therefore, based on our results, thermotolerance in the isolated strain of S. choleraesuis is relatively more than in S. typhimurium (ATCC 13311). It looks like that there is a wide range of thermotolerance variability of Salmonella among different serotypes and even among different isolates of the same serotype. It was reported that the $D$ values of Salmonella agona at the temperatures $60^{\circ} \mathrm{C}, 65^{\circ} \mathrm{C}$, and $70^{\circ} \mathrm{C}$ in buffered peptone solution were $148,19.8$, and $7.8 \mathrm{~s}$, respectively. These values are considered very high $D$ values for this serotype of Salmonella enterica, while the $D$ values of Salmonella typhimurium at the same temperatures were $13.2,6$, and $1.2 \mathrm{~s}$. It has been shown that the $Z$ value of Salmonella spp. ranged between 3.9 and $7.4^{\circ} \mathrm{C}$ [32] which is in accordance with the $Z$ value obtained in our study. However, their $D$ values are still higher and lower compared to our results.

It has been reported that the $D$ values at $60^{\circ} \mathrm{C}$ and $65^{\circ} \mathrm{C}$ of Salmonella spp. in beef meat were $8.6 \mathrm{~min}$ and $1.5 \mathrm{~min}$, respectively [4], while according to [34-36], the $D$ values of Salmonella spp. at the same temperatures and in the same product were 5.3 and $0.53 \mathrm{~min}$, respectively [33], indicating variability in the $D$ values of Salmonella spp. The main cause of the high values in the previously mentioned study could be due to lower water activity. In addition, Liu et al. [4] showed that $70^{\circ} \mathrm{C}$ is a critical temperature for Salmonella death, which is coherent with the results of the present study. Moreover, high thermotolerance of Salmonella in the aqueous solutions with high water activity was reported, where the heat treatment up to $85^{\circ} \mathrm{C}$ for 1 min did not eliminate the naturally occurring contaminant from alfalfa seeds [34]. This finding is in parallel with our results indicating that Salmonella can endure high temperatures in aqueous solutions.

In our study, statistical analysis showed a significant difference between the $D$ values of both bacteria $S$. choleraesuis and $S$. typhimurium under three temperatures $65^{\circ} \mathrm{C}, 70^{\circ} \mathrm{C}$, and $75^{\circ} \mathrm{C}$ (Fig. 1). Also, the thermotolerance superiority of $S$. choleraesuis on S. typhimurium was found. In addition, there was a significant difference between the obtained $Z$ values of both serotypes (were determined depending on the obtained $D$ values) 4.9 and 4.5 degree, respectively (Fig. 2). Growing both serotypes at the same conditions indicated that the difference in $D$ and $Z$ values is due to genetic factors and it is neither temporarily acquired nor due to the environmental conditions. These obtained results are consistent with the findings of Alvarez et al. [9], Dodier [35], and de Melo et al. [36], where it was reported that there is a difference in thermotolerance among S. senftenberg, S. typhimurium, and $S$. enteritidis serotypes.

\section{Relative gene expression analysis}

The expression of DnaK and HtrA genes in both serotypes was investigated to find out if there is a correlation between the expression of these genes and thermotolerance. Relative expression analysis using qRT-PCR was performed on the bacteria grown under different temperatures $\left(37^{\circ} \mathrm{C}, 42^{\circ} \mathrm{C}, 47^{\circ} \mathrm{C}, 50^{\circ} \mathrm{C}\right.$, and $55^{\circ} \mathrm{C}$ ), while the bacteria grown at $37^{\circ} \mathrm{C}$ were used as control. In our study, the relative gene expression of DnaK in S. choleraesuis at the different temperatures $37^{\circ} \mathrm{C}$ (control), $42^{\circ} \mathrm{C}, 47^{\circ} \mathrm{C}, 50^{\circ} \mathrm{C}$, and $55^{\circ} \mathrm{C}$ were $1.00,44.32,46.21$, 47.50, and 39.67, respectively (Fig. 3). The highest relative gene expression of $D n a K$ was at $50^{\circ} \mathrm{C}$, and then, its expression started to decline but not sharply. By contrast, the DnaK gene expression at the different temperatures in S. typhimurium were 1.0, 41.07, 47.18, 38.32, and 32.90 , respectively. It is obvious that the highest DnaK expression in S. typhimurium was at $47^{\circ} \mathrm{C}$, and these results are in the same ranges of previous measurements [8]. On the other hand, the HtrA relative expression was found to be higher in S. choleraesuis than 


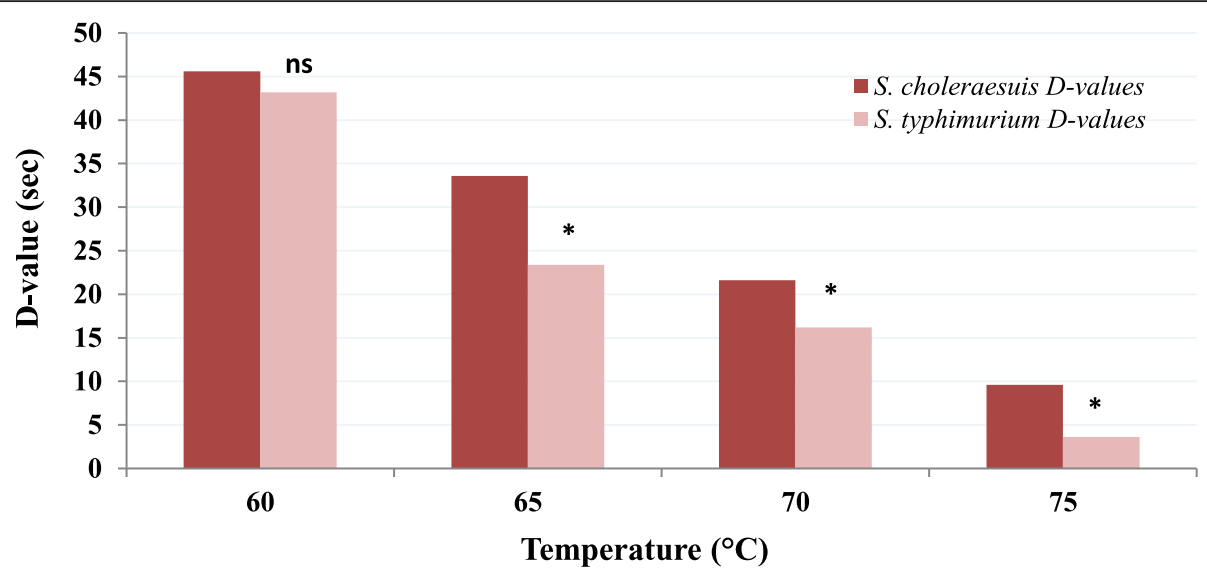

Fig. 1 Histogram comparing the D values of S. typhimurium and S. choleraesuis grown under different temperatures. *Significant difference between both bacteria at temperature. ns, no significant difference

in S. typhimurium (Fig. 4). The relative HtrA expression was $1.00,4.41,5.10,3.92$, and 4.17 , respectively, in $S$. choleraesuis, while it was $1.00,4.26,4.06,3.71$, and 3.78 , respectively, in S. typhimurium; this range of gene expression levels is matching with the results of Baron et al. [37], where they reported that the expression fold of HtrA after induction increased up to 4.83-7.79 times.
The highest $H$ trA expression was at $47^{\circ} \mathrm{C}$ in $S$. choleraesuis, while it was at $42{ }^{\circ} \mathrm{C}$ in $S$. typhimurium. Therefore, it is clear that the peak of relative gene expression of both heat shock genes (DnaK and HtrA) comes more lately in S. choleraesuis serotype.

Our results of qRT-PCR analysis showed that the relative expression of two studied heat shock genes DnaK

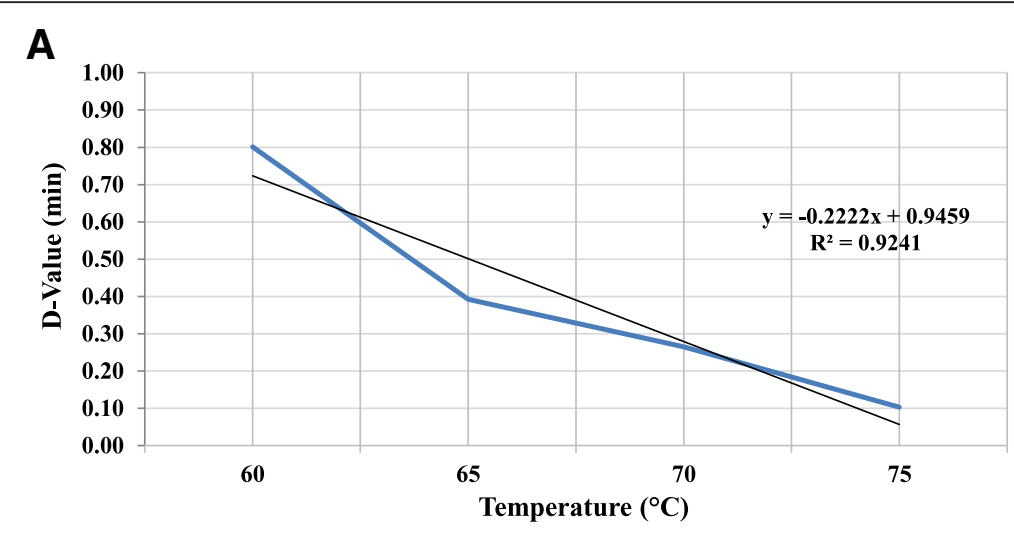

B

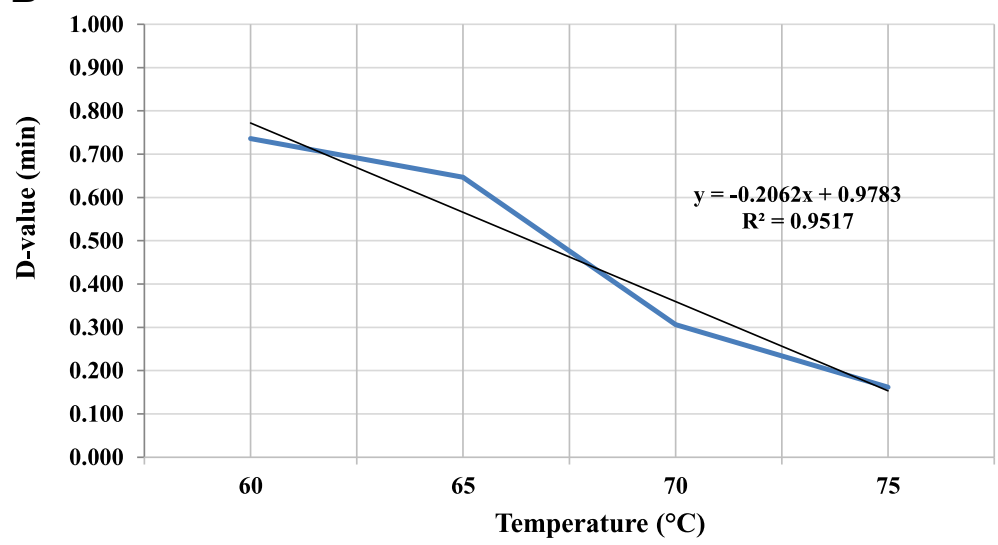

Fig. 2 Z value determination curves of S. typhimurium (a) and S. choleraesuis (b) grown under different temperatures 


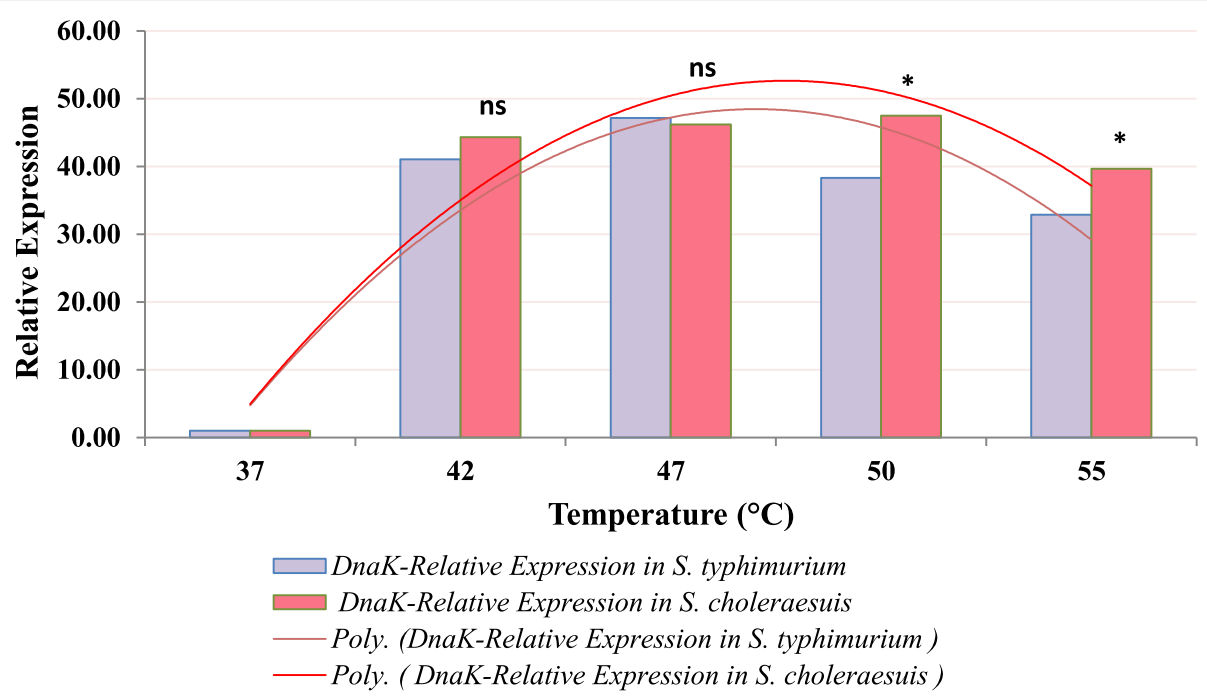

Fig. 3 Relative expression of DnaK gene in S. typhimurium and S. choleraesuis grown under different temperatures. *Significant difference between both bacteria at temperature. ns, no significant difference; Poly., polynomial curve

and HtrA increased with increasing temperature. These results are in accordance with the findings of Sirsat et al. [8], where they found that the expression of HtrA and DnaK were upregulated up to 4.11- and 44-fold, respectively, at temperatures over $40^{\circ} \mathrm{C}$. In addition, in this study, the gene expression of both genes DnaK and HtrA in both serotypes increased dramatically with increasing temperature. Moreover, when the temperature is shifted from 37 to $42{ }^{\circ} \mathrm{C}$, there was a sudden increase in gene expression indicating a threshold in this range of temperature, which is also coherent with the previously mentioned study [8]. Also, a significant difference in the relative expression of HtrA gene between S. typhimurium and S. enteritidis was reported, which was accompanied with relatively higher thermotolerance of $S$. typhimurium that has the higher gene expression [38]. This result is also in accordance with our results.

Comparing the results of relative gene expression of DnaK and HtrA in both serotypes using Tukey's multiple comparisons test indicated that the trend of relative expression of both genes is higher in S. choleraesuis than in S. typhimurium. Moreover, the difference of relative expression of both genes is significant and relative gene expression has a correlation with the bacterial

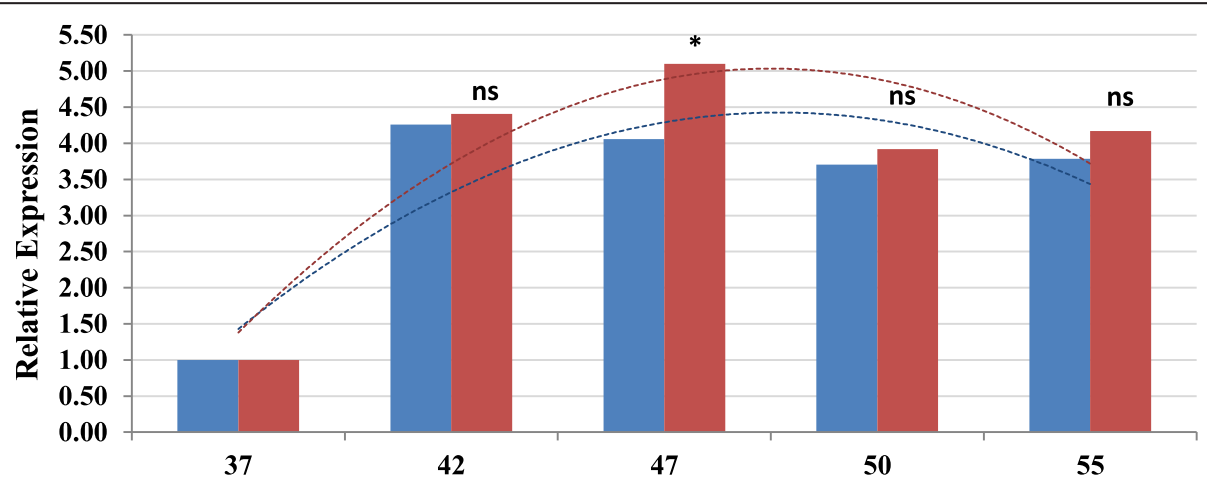

Temperature $\left({ }^{\circ} \mathrm{C}\right)$

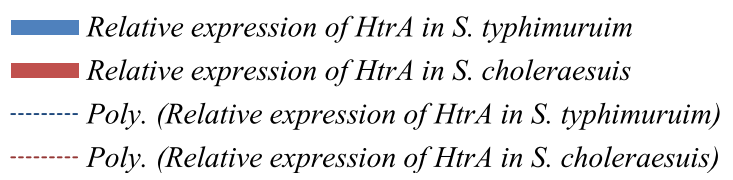

Fig. 4 Relative expression of HtrA gene in S. typhimurium and S. choleraesuis grown under different temperatures. *Significant difference between both bacteria at temperature. ns, no significant difference; Poly., polynomial curve 
thermotolerance. This result also meets the results of Yadav et al. [38] in their study on thermotolerance difference between S. typhimurium and S. enteritidis.

\section{Conclusions}

In this study, the tahini bacterial isolate was biochemically, molecularly, and immunologically identified as $S$. choleraesuis serotype. This identified serotype was found to be more thermotolerant than S. typhimurium ATCC 13311 (reference serotype) in aqueous solution with water activity of 0.98 , which was due to genetic basis although both serotypes belong to the same genus, species, and subspecies. This difference in thermotolerance was accompanied with higher relative expression of two heat shock genes DnaK and HtrA, which is probably the reason of relatively high thermotolerance of this bacterial isolate (serotype).

\section{Acknowledgements}

Not applicable.

\section{Authors' contributions}

RG and SF conceived and planned the experiments. SF carried out the experiments. $\mathrm{RG}, \mathrm{MH}$, and $\mathrm{KD}$ supervised the research experiments. $\mathrm{RG}$ took the lead in writing the manuscript. All authors read and approved the final manuscript.

\section{Funding}

Not applicable.

\section{Availability of data and materials}

The datasets used and/or analyzed during the current study are available from the corresponding author on reasonable request.

\section{Ethics approval and consent to participate}

Not applicable.

\section{Consent for publication}

Not applicable.

\section{Competing interests}

The authors declare that they have no competing interests.

\section{Author details}

${ }^{1}$ Botany Department, Faculty of Science, Tanta University, Tanta 31527, Egypt. ${ }^{2}$ Microbiology Department, Faculty of Agriculture, Ain Shams University, PO Box 68, Hadayek Shobra 11241, Cairo, Egypt.

Received: 29 August 2019 Accepted: 2 September 2019

Published online: 07 October 2019

\section{References}

1. Scallan E, Hoekstra RM, Angulo FJ, Tauxe RV, Widdowson MA, Roy SL, Jones JL, Griffin PM (2011) Foodborne illness acquired in the United States-major pathogens. Emerg Infect Dis 17(1):7-15. https://doi.org/10.3201/eid1701.P11101

2. Dawoud TM, Davis ML, Park SH, Kim SA, Kwon YM, Jarvis N, O'Bryan CA, Shi Z, Crandall PG, Ricke SC (2017) The potential link between thermal resistance and virulence in Salmonella: A Review. Front Vet Sci 4:93. https:// doi.org/10.3389/fvets.2017.00093

3. Osaili T, Griffis CL, Martin EM, Beard BL, Keener A, Marcy JA (2006) Thermal inactivation studies of Escherichia coli O157:H7, Salmonella, and Listeria monocytogenes in ready-to-eat chicken-fried beef patties. J Food Protect 69: 1080-1086

4. Liu S, Tang J, Tadapaneni RK, Yang R, Zhu M-J (2018) Exponentially increased thermal resistance of Salmonella spp. and Enterococcus faecium at reduced water activity. Appl Environ Microbiol 84:e02742-17. https://doi.org/ 10.1128/AEM.02742-17

5. Mercer RG, Zheng J, Garcia-Hernandez R, Ruan L, Gänzle MG, McMullen LM (2015) Genetic determinants of heat resistance in Escherichia coli. Front Microbiol 6:932. https://doi.org/10.3389/fmicb.2015.00932

6. Li H, Gänzle M (2016) Some like it hot: heat resistance of Escherichia coli in food. Front Microbiol 7:1763. https://doi.org/10.3389/fmicb.2016.01763

7. Shimizu K (2014) Regulation systems of bacteria such as Escherichia coli in response to nutrient limitation and environmental stresses. Metabolites 4:1):1-1)35

8. Sirsat SA, Baker CA, Park SH, Muthaiyan A, Dowd SE, Ricke SC (2015) Transcriptomic response of Salmonella typhimurium heat shock gene expression under thermal stress at $48^{\circ} \mathrm{C}$. J Food Res 4(5):51-56

9. Alvarez-Ordonez A, Fernandez A, Bernardo A, López M (2009) A comparative study of thermal and acid inactivation kinetics in fruit juices of Salmonella enterica serovar Typhimurium and Salmonella enterica serovar Senftenberg grown at acidic conditions. Foodborne Pathog Dis 6(9):1147-1155. https://doi.org/10.1089/fpd.2009.0313

10. Lipinska B, Fayet O, Baird L, Georgopoulos C (1989) Identification, characterization, and mapping of the Escherichia coli htrA gene, whose product is essential for bacterial growth only at elevated temperatures. J Bacteriol 171:1574-1584

11. Lewis C, Skovierova H, Rowley G, Rezuchova B, Homerova D, Stevenson A, Spencer J, Farn J, Kormanec J, Roberts M (2009) Salmonella enterica serovar Typhimurium HtrA: regulation of expression and role of the chaperone and protease activities during infection. Microbiology 155(3):873-881. https://doi. org/10.1099/mic.0.023754-0

12. Ghazaei C (2017) Role and mechanism of the Hsp70 molecular chaperone machines in bacterial pathogens. J Med Microbiol 66(3):259-265. https://doi. org/10.1099/jmm.0.000429

13. Mackey BM, Derrick C (1990) Heat shock protein synthesis and thermotolerance in Salmonella typhimurium. J Appl Microbiology 69(3):373-383

14. Schirmer EC, Glover JR, Singer MA, Lindquist S (1996) HSP100/Clp proteins: a common mechanism explains diverse functions. Trends Biochem Sci 21(8):289-296

15. Queitsch C, Hong S-W, Vierling E, Lindquist S (2000) Heat shock protein 101 plays a crucial role in thermotolerance in Arabidopsis. Plant Cell 12:479-492

16. Miot M, Reidy M, Doyle SM, Hoskins JR, Johnston DM, Genest O, Vitery MC, Masison DC, Wickner S (2011) Species-specific collaboration of heat shock proteins (Hsp) 70 and 100 in thermotolerance and protein disaggregation. Proc Natl Acad Sci USA 108:6915-6920. https://doi.org/10.1073/pnas. 1102828108

17. Mogk A, Kummer E, Bukau B (2015) Cooperation of Hsp70 and Hsp100 chaperone machines in protein disaggregation. Front Mol Biosci 2:22. https://doi.org/10.3389/fmolb.2015.00022

18. ISO: 6579 (2002) Standard methods of microbiology of food and animal feeding stuffs, international standards organization, horizontal method for the detection of Salmonella spp.

19. Green MR, Sambrook J (2012) Molecular cloning: a laboratory manual, 4th edn. Cold Spring Harbor Laboratory Press, Cold Spring Harbor, NY

20. Sanger F, Nicklen S, Coulson AR (1977) DNA sequencing with chainterminating inhibitors. Proc Natl Acad Sci USA 74(12):5463-5467. https://doi. org/10.1073/pnas.74.12.5463

21. Hall TA (1999) BioEdit: a user-friendly biological sequence alignment editor and analysis program for Windows 95/98/NT. Nucl Acids Symp Ser 41:95-98

22. Grimont PAD, Weill FX (2007) Antigenic formulae of the Salmonella serovars, 9th ed. Paris: World Health Organization Collaborating Center for Reference and Research on Salmonella, Institut Pasteur.

23. Hussein MA, Mar'i A-WS, Abu Ghurrah SM (2010) Estimate of thermal resistance of Salmonella in Tahini. Jordan J Agric Sci 6(4):664-674

24. Haimes J, Kelley M (2014) Dharmacon. A Horizon Discovery Group Company, Lafayette, CO, USA

25. Yoshida C, Gurnik S, Ahmad A, Blimkie T, Murphy SA, Kropinski AM, Nash JH (2016) Evaluation of molecular methods for identification of Salmonella serovars. J Clin Microbiol 54(8):1992-1998. https://doi.org/10.1128/JCM.00262-16

26. Wattiau P, Boland C, Bertrand S (2011) Methodologies for Salmonella enterica subsp. enterica subtyping: gold standards and alternatives. Appl Environ Microbiol 77:7877-7885. https://doi.org/10.1128/AEM.05527-11

27. Srinivasan R, Karaoz U, Volegova M, MacKichan J, Kato-Maeda M, Miller S, Nadarajan R, Brodie EL, Lynch SV (2015) Use of $16 \mathrm{~S}$ rRNA gene for 
identification of a broad range of clinically relevant bacterial pathogens. PLoS One 10(2):e0117617. https://doi.org/10.1371/journal.pone.0117617

28. Jeng K, Yang S, Won H, Gaydos CA, Hsieh YH, Kecojevic A, Carroll KC, Hardick J, Rothman RE (2012) Application of a 16S rRNA PCR-high-resolution melt analysis assay for rapid detection of Salmonella bacteremia. J Clin Microbiol 50(3):1122-1124. https://doi.org/10.1128/JCM.05121-11

29. Hellberg RS, Haney CJ, Shen Y, Cheng CM, Williams-Hill DM, Martin WB (2012) Development of a custom 165 rRNA gene library for the identification and molecular subtyping of Salmonella enterica. J Microbiol Methods 91:448-458. https://doi.org/10.1016/j.mimet.2012.09.018

30. Poretsky R, Rodriguez-R LM, Luo C, Tsementzi D, Konstantinidis KT (2014) Strengths and limitations of $16 \mathrm{~S}$ rRNA gene amplicon sequencing in revealing temporal microbial community dynamics. PLoS ONE 9(4): e93827. https://doi.org/10.1371/journal.pone.0093827

31. Beye M, Fahsi N, Raoult D, Fournier PE (2018) Careful use of 165 rRNA gene sequence similarity values for the identification of Mycobacterium species. New Microbes New Infect 22:24-29. https://doi.org/10.1016/.nmni.2017.12.009

32. Stopforth JD, Suhalim R, Kottapalli B, Hill WE, Samadpour M (2008) Thermal inactivation D- and Z-values of multidrug-resistant and non-multidrugresistant Salmonella serotypes and survival in ground beef exposed to consumer-style cooking. J Food Protect 71(3):509-515. https://doi.org/10 4315/0362-028X-71.3.509

33. Food Safety Authority of Ireland (2018) Report of the scientific committee, Ireland, ISBN 978-1-910348-14-7.

34. Suslow TV, Wu JC, Fett WF, Harris $L J$ (2002) Detection and elimination of Salmonella Mbandaka from naturally contaminated alfalfa seed by treatment with heat or calcium hypochlorite. J Food Protect 65:452-458

35. Dodier D (2015) Comparative study of the D-values of Salmonella spp. and Enterococcus faecium in wheat flour. Dissertation. University of NebraskaLincoln, USA

36. de Melo ANF, de Souza GT, Schaffner D, de Oliveira TCM, Maciel JF, de Souza EL, Magnani M (2017) Changes in thermo-tolerance and survival under simulated gastrointestinal conditions of Salmonella Enteritidis PT4 and Salmonella Typhimurium PT4 in chicken breast meat after exposure to sequential stresses. Int J Food Microbiol 251:15-23. https://doi.org/10.1016/j. ijfoodmicro.2017.03.022

37. Baron F, Bonnassie S, Alabdeh M, Cochet MF, Nau F, Guérin-Dubiard C, Gautier M, Andrews SC, Jan S (2017) Global gene-expression analysis of the response of Salmonella Enteritidis to egg white exposure reveals multiple egg white-imposed stress responses. Front Microbiol 8:829. https://doi.org/ 10.3389/fmicb.2017.00829

38. Yadav AS, Saxena GK, Saxena VK, Kataria JM (2016) Study on heat stress response in Salmonella Typhimurium and Salmonella Enteritidis and its impact on their attachment to dressed broiler skin surface. Asian J Animal Vet. Advances 11:114-121

\section{Publisher's Note}

Springer Nature remains neutral with regard to jurisdictional claims in published maps and institutional affiliations.

\section{Submit your manuscript to a SpringerOpen ${ }^{\circ}$ journal and benefit from:}

- Convenient online submission

- Rigorous peer review

- Open access: articles freely available online

- High visibility within the field

- Retaining the copyright to your article

Submit your next manuscript at $\boldsymbol{\nabla}$ springeropen.com 